2); die Polenz von Kö 592, die in Tabelle 2 angegeben wurde, bezicht sich nur auf die mittlere Hemmkonzentration $\left(\mathrm{IC}_{\text {;n }}\right)$.

Zusammenfassend kann man sagen, dass die 4 untersuchten Substanzen nur in erhöhten Konzentrationen (in Konzentrationen, die weit über den beta-adrenolytisch wirksamen liegen) die Serum-Cholinesterase der Ratte hemmen.

Der Autor dankt für die wertvolle Milarbeit den Herren Biagio Ungaro, Lucio Giordano und Ciro Vacea und für die freundliche Cberlassung von C. 39.089-Ba der ClBA A.G., von Propranolol der Imperial Chemical Industries Ltd., von $H 56 / 28$ der AB Astra und von $K \ddot{~} 592$ der Bochringer SOHN A.G.

Stmmary: The Beta-adrenolytic drugs propranolol, C. 39089-Ba, H $56 / 28$ and Kö 592 inhibit only in high concentrations the serum cholinesterase of the rat; Kö 592 is the least active.

\title{
REFERENCES
}

1) Illmann, G.L., Colirtney, K.D., Andres, V. and Featherstone, R.M.: Biochem. Phamac. 7, 88 (1961): 2) FINNFY, D.J.: Probit Analysis, Cambridge University Press, London (1952);

3) Marmo, E., Coscia, L. and Magliulo, S.: II Farmaco (Ed. Sci.) 22, 735 (1967); 4) Marmo, E., Coscin, L., Matera, A. And Aulisio, G.A.: Afch. Ital. Laringol. 75, 249 (1967); 5) Marmo, E, Coscta, L. nNd Mitera, A.: Afzhcim-Forsch. 18, 143 (1968): 6) Marmo, E., Coscia, L. And Matera, A.: Cardiologia, Basel 52, 177 (1969)

\section{BINDING SITE OF OUABAIN IN CARDIAC MUSCLE CELL AND ITS POSITIVE INOTROPIC EFFECT IN CAT}

\author{
Sumiko FUJINO, Shunsaku KAWAGISHI, Noriyasu EGUCHI \\ and Mamoru TANAKA \\ Department of Pharmacology, Sapporo Medical Collere, Sapporo
}

Received for publication March 3, 1971

A study was conducted to know the significance of ouabain-binding to various structural components of cardiac muscle cell in appearance of the positive inotropic effect. A special attention was paid to the binding capacity in two kinds of membrane system, sarcoplasmic reticulum (SR) and cell membranc, since it has been pointed out that Ca-mobilizing effect of cardiac glycosides on SR and/or cell membrane is responsible for the positive inotropic effect (1-3), suggesting a selective affinity of the glycosides to a cellular component.

In the first series of experiments, a treatment with ouabain $\left(10^{-7} \mathrm{M}\right)$-perfusion for 30 minutes at $37 \mathrm{C}$ followed by 5 minutes of washout-perfusion was made, using Langendorff heart of the cat. At the end time-point of the treatment, when the positive inotropic effect was manifest on the mechanogram, three kinds of observation were done; $l$ ) deter- 
mination of the activity of $\mathrm{Na}^{+}-\mathrm{K}^{+}$ATPase prepared by Akera's procedure $\left.(4), 2\right)$ that of subcellular distribution of ${ }^{3} \mathrm{H}$-ouabain by the use of a fractionation (nuclear fr.: 600 $\times \mathrm{g}$, mitochondrial fr.: $600 \times \mathrm{g}-12,000 \times \mathrm{g}$, microsomal fr., i.e., SR fr.: $12,000 \times \mathrm{g}-150,000$ $\times \mathrm{g})$, and 3) that of ${ }^{45} \mathrm{Ca}$-quantity in each fraction. In the third observation, a perfusion with a Ringer containing ${ }^{45} \mathrm{Ca}$ for 30 minutes at $37^{\circ} \mathrm{C}$ was made before the ouabain-perfusion, in order that ${ }^{45} \mathrm{Ca}$ was substituted for $\mathrm{Ca}$ in each intracellular component. In the second series of experiments, SR and cell membrane were first prepared from heart and skeletal muscles of cat (SR, procedure of Ineshi (5); cell membrane, procedure of Hotta (6); both with slight modifications), and then, the preparations were soaked in a medium containing ${ }^{3} \mathrm{H}$-ouabain $\left(10^{-\tau} \mathrm{M}\right)$ for 30 minutes at $37^{\circ} \mathrm{C}$, the condition being simulated to that of the first series of experiments.

In the first series of experiments, it was found at the stage with a manifest positive inotropic effect of ouabain that no measurable inhibition of $\mathrm{Na}^{+}-\mathrm{K}^{+}$ATPase activity appeared, and that quantity of ${ }^{15} \mathrm{Ca}$ in SR was reduced by about $20 \%$ as compared with the case without the ouabsin-treatment, indicating the Ca-mobilizing effect of ouabain on SR. Table 1 shows a summary of the results on subcellular distribution of ouabain applied extracellularly in heart at the stage with the manifest positive inotropic effect. In these observations, two points are interesting: I) A stage was found that $\mathrm{Na}^{+}-\mathrm{K}^{+}$ATPase activity is not inhibited in presence of manifest positive inotropic effect of ouabain, and 2) the greatest binding of ouabain is seen in SR fr., of which $\mathrm{Ca}$ is mobilized by the drug considerably. Experiments of this series show, furthermore, that binding of ouabain in the SR fr. reaches already a saturation by the ouabain-treatment for 30 minutes.

Table 2 shows a summary of the results on the sccond series of experiments, in which preparations were first obtained and then incubated with ${ }^{3} \mathrm{H}$-ouabain, and shows the capacity for binding of ouabain in isolated SR and cell membrane of heart and skeletal muscles.

TAri.l: 1. Subcellular distribution of ouabain in Langendorff cat heart at significant positive inotropic stage.

\begin{tabular}{lcc}
\multicolumn{1}{c}{ Subcellular fractions } & \multicolumn{2}{c}{ Binding of oubain } \\
& $\begin{array}{c}\text { pmoles } / \text { mg protein } \\
\text { (Mean SE) }\end{array}$ & Ratio \\
Microsomal fr. (i.e. SR fr.) & $5.71 \ldots 0.56$ & 1 \\
Mitochondrial fr. & $0.33 \pm 0.04$ & 0.06 \\
Nuclear fr. & $0.40 \pm 0.04$ & 0.07 \\
\hline
\end{tabular}

TABLF 2. Binding of ouabain to sarcoplasmic reticulum and cell membrane prepared from cat heart and skeletal muscle.

\begin{tabular}{|c|c|c|c|c|}
\hline \multirow{3}{*}{ Preparations } & \multicolumn{4}{|c|}{ Binding of ouabain } \\
\hline & \multicolumn{2}{|c|}{ Heart muscle } & \multicolumn{2}{|c|}{ Skeletal muscle } \\
\hline & $\begin{array}{c}\text { pmolesimg protein } \\
\text { (Mean SE) }\end{array}$ & Ratio & $\begin{array}{c}\text { pmoles/mg protein } \\
(\text { Mean }-\mathrm{SE})\end{array}$ & Ratio \\
\hline SR fragments & $5.70: 0.15$ & 1 & $3.70: 0.20$ & 1 \\
\hline Cell membranes & $0.66 \div 0.04$ & 0.12 & $0.35 \pm 0.05$ & 0.09 \\
\hline
\end{tabular}


Binding of the drug to both preparations reached an equilibrium in 10 minutes. The table gives such an equilibrium value and demonstrates that the cell membrane exhibits very poor capacity for binding of ouabain and the capacity in the membrane is approximately one-tenth that found for the SR.

From the comparison of the results on heart muscle between Tables 1 and 2, it would be interesting to note that binding of ouabain to SR fr. (Table 1) was almost of same value regardless of whether ouabain was given to muscle extracellularly or intracellularly. On the basis of the relationship, it could be said that quantity of ouabain in cell membrane of the Langendorff heart must be very small at the positive inotropic stage.

How the present results should be integrated for understanding the mechanism in the positive inotropic effect of ouabain is at present not conclusive, but the following could be pointed out: 1) Bound ouabain in cell membrane cannot be excluded, since the drug is considered to exist there already at the stage with the positive inotropic effect alone. 2) SR-bound ouabain which reaches through cell membrane is also interesting, since not only the quantity is high to show an intense affinity, but also the SR is an important storesite of $\mathrm{Ca}$ that is considered to control the contractile machinery of muscle cell. The second view agrees well with the previous work (7) on ouabain-microinjection that, even in skcletal muscle in which couabain does not permeate through cell membrane and not give a positive inotropic effect, the drug applied intracellularly can potentiate contractile responses.

\title{
REFERENCES
}

1) Nayler, W.G.: Am. Heart J. 73, $379(1967)$; 2) Klaus, K. and Lee, K.S.: J. Pharmac. exp. Ther. 166, 68 (1967); 3) Schatzmann, H.J.: Arch. Pharmak. exp. Path. 263, 11 (1969); 4) Aklra, T., Larsin, F.S. ANd Brody, T.M.: J. Pharmac. exp. Ther. 170, 17 (1969); 5) Ineshi, G., Ebashi, S. and Watanabe, S.: Am. J. Physiol. 207, 1339 (1964); 6) Hotta, K. and Usami, Y.: J. Biochem. 61, 407 (1967); 7) Fujino, S., TANaka, M. AND Fujino, M.: Nature, Lond. 223, $413(1969)$

\section{EFFECT OF COLD STRESS ON ACETYLCHOLINE CONTENT OF RAT MYOCARDIUM AND ITS MODIFICATION BY ATROPINE}

\author{
N.K. KHANNA \\ Department of Pharmacology, Dr. S.N. Medical College, Jodhpur, Rajasthan, India
}

Received for publication March 10, 1971

The present communication deals with the effect of cold stress on the acetylcholine content of rat myocardium and its modification by atropine.

Twenty-eight albino rats of both sexes, weighing between 90 and $150 \mathrm{~g}$, were divided into 4 groups. Animals in the first group served as control. The rats of the second 